\title{
A Group-C Ring Chromosome in a Mentally Deficient Male*
}

\author{
A. J. THERKELSEN, BODIL MØLLER, and K. HENNINGSEN
}

\author{
From the Institute of Medical Microbiology, University of Aarhus, Aarhus, the Childrens Department, Institute for \\ Mentally Retarded, Hald Ege, Viborg, and the Institute of Forensic Medicine, University of Copenhagen, \\ Copenhagen, Denmark
}

Ring chromosomes in association with different congenital anomalies have been described in a number of cases (see the review by Varela and Sternberg, 1969).

A ring chromosome involving a group- $\mathrm{C}$ chromosome in males has only been described in three cases as far as we know: one by Turner et al (1962), and two by Atkins et al (1966). The present paper reports on one further case of a ring chromosome replacing one of the chromosomes of the $\mathrm{C}$-group in a mentally deficient male.

\section{Case Report}

The patient is a 17-year-old boy born when his mother was 36 and his father 37 years old. The pregnancy and delivery were uncomplicated, but the patient was anoxic and cyanotic for a few minutes after delivery. Birth weight was $3750 \mathrm{~g}$ and length $54 \mathrm{~cm}$. The patient is the youngest of 3 children. Two elder sisters are normal and healthy, and so is the mother; the father suffers from Menière's disease. The father has a brother who is 65 and who has been institutionalized since he was 24 because of mental defect (IQ 52).

The motor and mental development of the patient was very slow. He walked without support at the age of 21-3 years, and was not toilet-trained until about 7 years. At age 4 months he was referred to the paediatric department of the Aarhus Municipal Hospital because of suspected mental and physical retardation. On physical examination the principal findings were that the cranium was pointed upwards with pronounced crista along the sutura sagittalis, the eyes were close-set (pupil distance $33 \mathrm{~mm}$ ), there was pronounced strabismus convergens, and slight epicanthus. At 5 years of age the patient was institutionalized and, apart from short visits to his home, has been kept in the institution ever since. Since he was 9 years old he has been treated with various psycho-pharmaca because of unrest. Psychological

\footnotetext{
Received 16 June 1970

* This study was supported by grants from the Danish State Research Foundation and the Research Foundation of the University of Aarhus.
}

examination at 15 years of age showed the development of language to be better than his other abilities. He makes understandable sentences, but often his speaking is fragmentary and without meaning. $\mathrm{He}$ is restless with short periods of excitement, confusion and fabulation. Binet's test gave an IQ of 28 .

Physical examination at the age of 16 showed his height to be $159 \mathrm{~cm}$ and his weight $62.1 \mathrm{~kg}$. The distribution of fat was feminine (see Fig. 1). The frontal region of the cranium was formed like a keel and the occipital region was flat with a horizontal prominence. The eyes were close-set; the palpebral fissures were small, without any mongoloid slant, but with slight epicanthus especially on the right side. Eye movements to the right were slightly paretic, and extreme movement elicited a nystagmus. The ears were small but not malformed. The chest was slightly funnel-shaped. The testes were soft and small, measuring $2 \times 3 \mathrm{~cm}$. The toes were malformed on both sides with a very long second toe. The third and especially the fourth toe were displaced proximally, the fourth partly covering the third and fifth (see Fig. 1). The skin showed keratosis pilaris on the back and on the front of the chest, and striae distensae were found on the upper arms and on the buttocks.

X-ray examinations. The cranium was largely normal apart from the abnormal form. There were no signs of dysostosis. Examination of the vertebral column showed fusion of vertebrae Nos. 3 and 4, and 5 and 6 . His hands were normal, and examination of the feet showed short third and fourth metatarsals (Fig. 2).

Laboratory investigations. The pituitary gonadotrophins in the urine were elevated at 15 and 16 years of age, but had become normal at 17 years of age. All other investigations, including serum concentrations of phosphorus, calcium, protein-bound iodine, proteins, and amino acids were normal. The concentrations in urine of aminoacids and ketosteroids were also normal. Electrocardiography and encephalography showed no abnormalities.

Chromosome analysis. The karyotype of the patient was first investigated when he was 15 years old, 


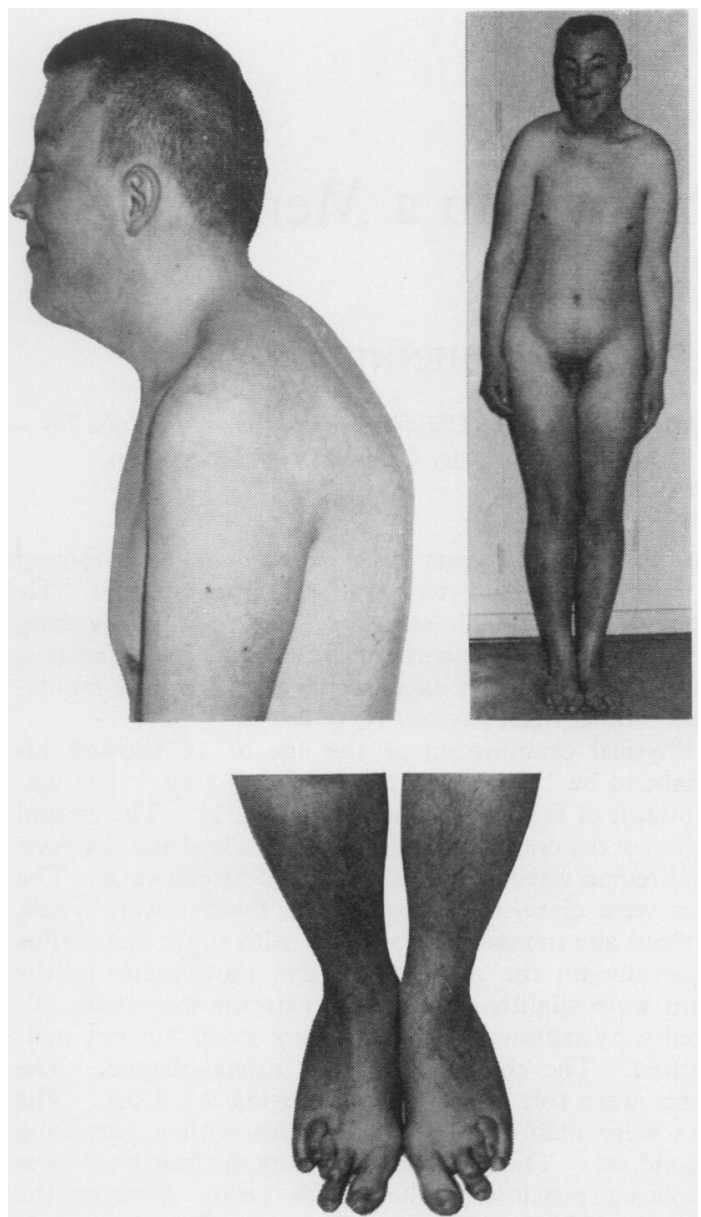

FIG. 1. The patient, showing also the abnormalities of the feet.

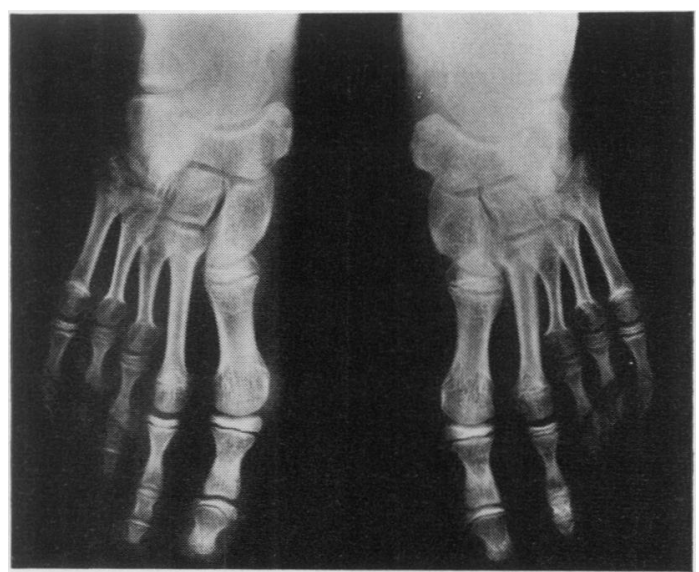

FIG. 2. Radiograph of the feet showing the short third and fourth metatarsals.
TABLE I THE CHROMOSOME COUNTS IN BLOOD AND SKIN

(The figures in brackets indicate the number of cells in which the ring chromosome was present)

\begin{tabular}{|c|c|c|c|c|c|c|}
\hline \multirow[t]{2}{*}{ Culture } & \multicolumn{5}{|c|}{ Chromosome Count } & \multirow{2}{*}{ Total } \\
\hline & $\leqslant 44$ & 45 & 46 & 47 & 48 & \\
\hline Blood 1 & $\begin{array}{l}1(1) \\
0\end{array}$ & $\begin{array}{l}3(0) \\
3(2)\end{array}$ & $\begin{array}{l}25(25) \\
27(27)\end{array}$ & $\begin{array}{l}0 \\
0\end{array}$ & $\begin{array}{l}0 \\
0\end{array}$ & $\begin{array}{l}29 \\
30\end{array}$ \\
\hline $\begin{array}{ll}\text { Skin } & \frac{1}{2} \\
& \end{array}$ & $\begin{array}{l}0 \\
0\end{array}$ & $\begin{array}{l}1(1) \\
3(1)\end{array}$ & $\begin{array}{l}27(26) \\
41(41)\end{array}$ & $1\left(1^{*}\right)$ & $\begin{array}{l}1(1) \\
0\end{array}$ & $\begin{array}{l}30 \\
44\end{array}$ \\
\hline Total & $1(1)$ & $10(4)$ & $120(119)$ & $1\left(1^{*}\right)$ & $1(1)$ & $133(126)$ \\
\hline
\end{tabular}

* Two ring chromosomes present.

and the investigation was repeated 2 years later. On both occasions the analysis was done with blood cultures as well as with cultures from a skin biopsy specimen. The results of the chromosome counts are seen in Table I. All cells were analysed, and out of the 120 modal cells 119 had a ring chromosome which replaced one of the chromosomes in the C-group. These 119 cells therefore had the karyotype $46, \mathrm{XY}, \mathrm{Cr}$. The ring chromosome seemed of the same relative size in all the cells apart from 4 modal cells ( 3 from blood and 1 from skin), where the ring was about doubled in size and seemed to have two centromeres. The one modal cell missing the ring had the normal male karyotype $46, \mathrm{XY}$. Figure 3 shows the C-group from 7 karyotypes. The last one has a double-size dicentric ring.

As appears from Table $I$ the ring chromosome was the one chromosome missing in 6 out of the 10 cells with 45 chromosomes. The one cell with 47 chromosomes had two ring chromosomes $(47, \mathrm{XY}, \mathrm{Cr}, \mathrm{Cr}+)$. The one cell with 48 chromosomes was $48, \mathrm{XY}, \mathrm{Cr}, \mathrm{B}+, \mathrm{F}+$.

The patient was sex chromatin negative in buccal smears.

The karyotypes of his parents were analysed in blood cultures as well as in cultures from a skin biopsy specimen, and both were found normal. The karyotype of the father's brother (who was institutionalized because of mental defect) was also normal.

Dermatoglyphs. The hands were slender with lowset thumbs. Digits IV and V were short compared to the other fingers. The finger patterns consisted of 5 whorls and 4 loops. The tip of digit $\mathrm{V}$ on the right side was amputated after an accident. The total ridge count was $112+98$ without correction for the missing finger. Correction by addition of the ridge count from the left digit $\mathrm{V}$ makes the total ridge count 237 , which is close to the upper $95 \%$ confidence limit for males, which according to Holt $(1968$, p. 55$)$ is about 238 (average for males: 142). The palmar triradius was situated at $t^{\prime \prime}$. The feet showed short halluces and a broad first interdigital space, and some of the main lines had a longitudinal course. 


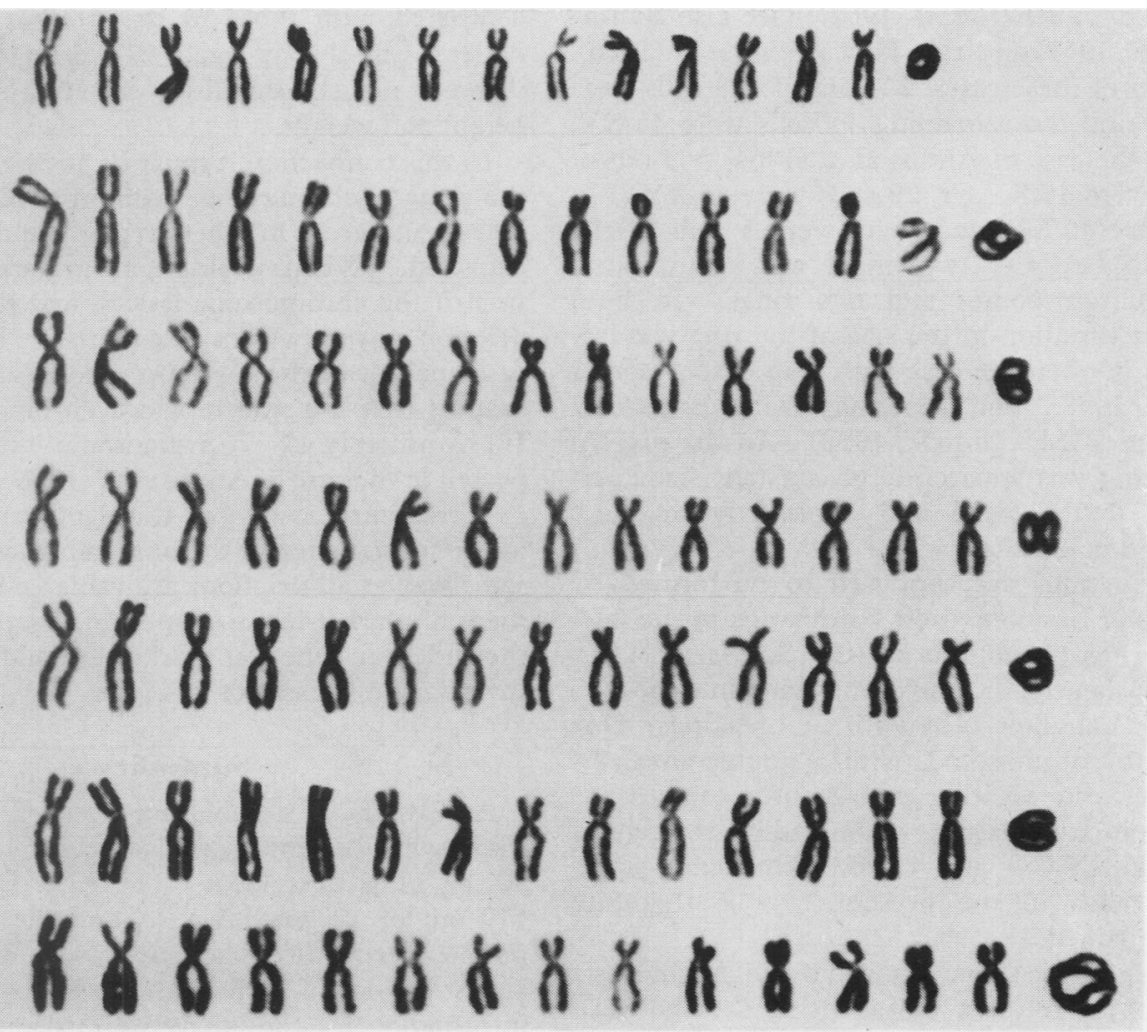

Fig. 3. The C-group from 7 karyotypes. The upper 6 show the monocentric ring found in most cells and the lowest shows a double-size dicentric ring.

Blood, serum, and enzyme types. The results of blood and serum type examinations are given in Table II. Within the Rh-system mother and child did not show the usual reaction pattern. Both had the C-factor but gave negative or very weakly positive reactions with some normally very potent anti-C sera and the child reacted negatively with some anti-e sera, positively with others. This may well be due to a depressed gene $\mathrm{D}(\mathrm{Ce})$ as described by Broman et al (1963), and there is no evidence of a relationship to the chromosome abnormality as the mother does not have a ring chromosome. The reaction pattern and segregation was found to be normal in all the other systems.
As a chromosomal segment is usually deleted when a ring chromosome is formed, a marker gene located in this would be hemizygous, which might be disclosed by the parent-child combination. Bearing in mind that by the given parent-constellation only the $\mathrm{MN}$ - and $\mathrm{AK}$ systems are able to be informative in this respect such evidence has not been found.

\section{Discussion}

The ring chromosome described was very stable, as it was present in 126 out of 133 cells analysed. Cytogenetically the case is very similar to the case

TABLE II

BLOOD, SERUM, AND ENZYME TYPES FOR THE PATIENT AND HIS PARENTS

\begin{tabular}{|c|c|c|c|c|c|c|c|c|c|c|c|c|c|c|c|c|c|c|c|c|}
\hline \multirow{2}{*}{ Subject } & \multirow{2}{*}{ ABO } & \multicolumn{6}{|c|}{ Rhesus } & \multirow{2}{*}{ MNS } & \multirow{2}{*}{$\mathbf{P}$} & \multirow{2}{*}{$\mathbf{K}$} & \multirow{2}{*}{$K p^{a}$} & \multirow{2}{*}{$F^{a}$} & \multirow{2}{*}{ Hp } & \multirow{2}{*}{ Gc } & \multicolumn{2}{|r|}{$\mathrm{Gm}$} & \multirow{2}{*}{$\mathbf{P G M}_{1}$} & \multirow{2}{*}{$\mathrm{PGM}_{3}$} & \multirow{2}{*}{$\underset{\substack{\text { Acid } \\
\text { tase }}}{\text { Phospha- }}$} & \multirow{2}{*}{$\begin{array}{c}\text { Adeny- } \\
\text { late- } \\
\text { kinase }\end{array}$} \\
\hline & & C & $\mathrm{CW}^{\mathrm{w}}$ & $\mathbf{D}$ & $\mathbf{E}$ & c & e & & & & & & & & & $\mathbf{x} \quad \mathbf{b}$ & & & & \\
\hline $\begin{array}{l}\text { Patient } \\
\text { Father } \\
\text { Mother }\end{array}$ & $\begin{array}{l}\mathbf{A}_{\mathbf{1}} \\
\mathbf{B} \\
\mathbf{A}_{\mathbf{1}}\end{array}$ & $\begin{array}{l}(+) \\
+ \\
(+)\end{array}$ & $\begin{array}{l}- \\
-\end{array}$ & $\begin{array}{l}+ \\
+ \\
+\end{array}$ & $\begin{array}{l}+ \\
+ \\
-\end{array}$ & $\begin{array}{l}+ \\
+ \\
+\end{array}$ & \pm & $\begin{array}{l}\text { MNSS } \\
\text { MNSS } \\
\text { MMSS }\end{array}$ & $\begin{array}{l}- \\
+ \\
+\end{array}$ & $\bar{z}$ & - & $\begin{array}{l}+ \\
+ \\
+\end{array}$ & $\begin{array}{l}2-2 \\
2-2 \\
2-2\end{array}$ & $\begin{array}{l}1-1 \\
1-1 \\
1-1\end{array}$ & & $\begin{array}{ll}- & - \\
- & + \\
- & +\end{array}$ & $\begin{array}{l}2-2 \\
2-1 \\
2-1\end{array}$ & $2-1$ & $\underset{\text { B }}{\text { B }}$ & $\begin{array}{l}2-1 \\
2-1 \\
1-1\end{array}$ \\
\hline
\end{tabular}


described by Turner et al (1962); (see also SmithWhite et al, 1963) and case II of Atkins et al (1966). In the first of these cases, 244 out of 288 cells were $46, \mathrm{XY}, \mathrm{Cr}$ and the remaining 44 cells were $45, \mathrm{XY}$, $\mathrm{C}-$. In the case of Atkins et al (1966) 365 out of 418 cells were $46, \mathrm{XY}, \mathrm{Cr}, 26$ cells were $45, \mathrm{XY}, \mathrm{C}$ - , 4 cells were $46, X Y$, and there were 5 cells of the type 47,XY,Cr,Cr + (two rings), and also one cell with 48 chromosomes and two rings. In both cases great variation in the size of the ring was observed, as is often the case with ring chromosomes (Lejeune, 1968), and especially with large ring chromosomes (McClintock, 1938). In the present case the ring was apparently of constant size apart from the double-sized and apparently dicentric rings found in 4 cells.

Dicentric rings are supposed to be formed by crossing over between sister chromatids in the normal-sized rings (McClintock, 1938; Schwartz, 1953). At cell division the dicentric ring sometimes goes to one of the daughter cells without breaking. One cell gets 46 chromosomes with a double-sized dicentric ring, and the other gets 45 chromosomes, the ring chromosome missing. The finding of 6 cells of the type 45,XY,C - and 4 cells with double-sized, dicentric rings in the present case is therefore readily explained.

The frequency of double-sized dicentric rings is a measure of the frequency of crossing over between sister chromatids, and the frequency will increase with the size of the ring. McClintock (1938) found a frequency of 8 per cent for a large ring in maize, whereas Schwartz (1953) found a frequency of $4.5 \%$ for a smaller ring. The frequency in the present case is 4 out of 126 cells, or $3 \cdot 2$ per cent.

The observed variation in size of the monocentric rings (McClintock, 1938; Lejeune, 1968) is explained by breakage and rejoining of the dicentric ring during cell division, each daughter cell getting a monocentric ring. However, as the point of breakage is randomly placed on the ring, the two rings may have different sizes, and in a population of cells the sizes of the ring may vary continuously. A variation of this type was not characteristic of the present case, but small variations in the size can never be excluded.

The clinical manifestations in the present case are different from those found in the case of Turner et al (1962). The patient was a 12-year-old boy, and the main manifestations were severe mental defect (IQ 30), congenital heart disease (atrial septal defect), hypospadias and an unusual amount of fine hair all over the body. The clinical manifestations of case II of Atkins et al can scarcely be compared with those in the present case, as the patient was a boy aged $2 \frac{1}{2}$ years, but this boy showed no abnormalities apart from very low height and weight.

In this connection it must be stressed that even if the same C-chromosome were involved in all three cases, similarity in phenotypes could scarcely be expected. When a ring chromosome is formed part of the chromosome is lost, and the size of the deletion may vary from case to case. In the present case analysis of the $\mathrm{C}$-group chromosomes made us suspect that the ring replaced chromosome No. 9, 10 , or possibly 12 . Chromosome No. 10 was suspected in the case of Atkins et al (1966).

A ring chromosome of this type may be of value in the construction of the human linkage map, in the same way as all deletions are valuable in the assignment of marker loci to a specific chromosome. All the different genetical markers should therefore be investigated in cases of this type.

\section{Summary}

A 17-year-old male with a group-C ring chromosome which seems to replace chromosome No. 9, 10 , or 12 is described. The ring was present in 119 out of 120 modal cells, and the frequency of double-sized, dicentric rings was 3.2 per cent. Investigation of genetical markers gave linkage information for the adenylate kinase and $\mathrm{MN}$ loci only.

The authors are greatly indebted to $\mathrm{Dr}$ Gunner Schmidt, the Institution for the Mentally Retarded in Brejning, for performing the dermatoglyphic analysis, and to Miss Sonja Rou Jensen and Mrs Lis Vestergaard for skilful technical assistance.

\section{REFERENCES}

Atkins, L., Pant, S. S., Hazard, G. W., and Ouellette, E. M. (1966). Two cases with a C-group ring autosome. Annals of Human Genetics, 30, 1-6.

Broman, B., Heiken, A., Tippett, P. A., and Giles, C. M. (1963). The $\mathrm{D}(\mathrm{C})(\mathrm{e})$ gene complex revealed in the Swedish population. Vox Sanguinis, 8, 588-593.

Holt, S. B. (1968). The Genetics of Dermal Ridges. Thomas, Springfield, Illinois.

Lejeune, J. (1968). De la duplication de structures circulaires. Annales de Génétique, 11, 71-77.

McClintock, B. (1938). The production of homozygous deficient tissues with mutant characteristics by means of the aberrant mitotic behaviour of ring-shaped chromosomes. Genetics, 23, 315-376.

Schwartz, D. (1953). Evidence for sister-strand crossing over in maize. Genetics, 38, 251-260.

Smith-White, S., Peacock, W. J., Turner, B., and Dulk, G. M. den (1963). A ring chromosome in man. Nature, 197, 102-103.

Turner, B., Jennings, A. N., Dulk, G. M. den, and Stapleton, T. (1962). A self-perpetuating ring chromosome. Medical fournal of Australia, 49 (2), 56-58.

Varela, M. A. and Sternberg, W. H. (1969). Ring chromosomes in two infants with congenital malformations. Fournal of Medical Genetics, 6, 334-341. 